\title{
Television program ratings and informed audiences
}

\author{
Victoria Tur-Viñes
}

Nota: Este artículo se puede leer en español en:

http://www.elprofesionaldelainformacion.com/contenidos/2020/mar/tur_es.pdf

How to cite this article:

Tur-Viñes, Victoria (2020). "Television program ratings and informed audiences". El profesional de la información, v. 29, n. 2, e290212.

https://doi.org/10.3145/epi.2020.mar.12

Manuscript received on $12^{\text {th }}$ July 2019 Accepted on $13^{\text {th }}$ November 2019

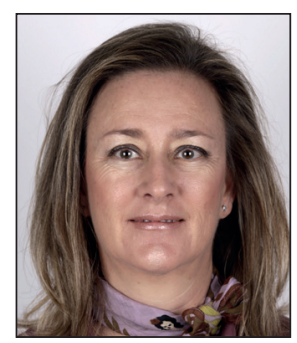

\author{
Victoria Tur-Viñes $\square$ \\ https://orcid.org/0000-0002-8442-8068 \\ Universidad de Alicante \\ Edificio Ciencias Sociales \\ 03690 San Vicente del Raspeig (Alicante), Spain \\ victoria.tur@ua.es
}

\begin{abstract}
This paper is positioned at the intersection between the concepts of informed audiences, media literacy, and television content ratings. It begins with a definition of the first two concepts, followed by a consideration of ratings as a mechanism at the service of both. An analysis is offered of the most notable international initiatives (Australia, USA, UK, and The Netherlands), as well as the Spanish case and its associated actions. Rating procedures are necessary mechanisms to facilitate well-informed viewing decisions by TV audiences, especially in the case of children's programming. This article proposes recommendations in relation to the implementation of the European audiovisual media services directive, including the use of a wide range of pictograms to identify types of content.
\end{abstract}

\section{Keywords}

Audience; Television; Multimedia; Informed audience; Media literacy; Television rating systems; Television quality; General public; Pictograms; European directives; Audiovisual media; Children; Audiovisual product labelling.

\section{Introduction}

\subsection{Concept of audience}

"Audience" is a useful social conception in media management, as it groups together members of the public interested in interacting with content broadcast by the media. In this sense, the idea of audience moves beyond the passiveness normally ascribed to it and encompasses its productive, creative and conversational dimension.

In the current literature, with the rise of interactivity and second screens, the notion of audience is evolving from its conception as a merely active consumer towards a more social perspective. The so-called "social audience" (Quintas-Froufe; González-Neira, 2015) reflects a kind of viewer behaviour characterised by universal and dynamic access to content online and by active, dynamic and universal participation that can even influence the narrative of the content itself, feeding off a vertical exchange with the broadcaster/producer/distributor and a horizontal exchange with other followers with the same interests. In this way, user consumption becomes experiential and the passive attitude of the viewer turns into a reaction of engagement (commitment+involvement) with the media (Saavedra-Llamas; Rodríguez-Fernández; Barón-Dulce, 2015; Tur-Viñes, 2015).

The rise in interactivity as a form of audience participation, according to Cover (2006), responds to an intense cultural desire to take part in the creation and transformation of content, which was not possible with previous technologies. The notion of television audiences as members of the general public who consume media content is not new (Dahlgren, 1995; Hartley, 1999), nor is the view of interacting with television as a sociocultural experience (Dahlberg, 2007; Quin- 
tas-Froufe; González-Neira, 2016). However, although the idea of an informed audience was also first suggested in the 1990s (Hagen, 1997), its analysis as a mechanism for media literacy has only begun to be consolidated quite recently.

The development of the kind of enhanced knowledge that can help viewers to make decisions is a natural consequence of policies geared towards the creation of an informed audience. Competent, literate users can make better decisions when they have more information about content. Such information changes the meaning that viewers ascribe to content and encourages the appropriation of knowledge. In this way, decisions related to choosing, viewing and interpreting audiovisual content are made on the basis of a more positive emotion-reason-context balance.

The conception of the informed audience is closely associated with decision making based on sufficient, reliable and truthful information. Providing the right information for decision making is viewed as extremely important in the field of healthcare (informed consent), where it has been an object of study for many years.

In studies of television, the informed audience has become a focus of research in the context of journalistic content related to information or news. According to Marton \& Säljö (1984), the informed audience needs to make a significant cognitive effort to achieve understanding and learning. This profound effort requires the user to engage intensely with the news, questioning the intentions of the journalist, analysing the details and relating the content to a broader context. In the field of sports journalism, a well-informed audience is reflected in a neutral attitude, not clinging to opinions, moderate, with extensive knowledge and not inclined to overreact (Abalasei, 2012). Other authors suggest that most viewers are unaware of the consequences of their own viewing decisions, and Aznar-Gómez (2011), among others, argues that this state of ignorance or disinformation limits their freedom, making it imperative to adopt decisive strategies to promote a media culture. Such strategies, which would help consolidate the media competence of the general public, should be present in public policy on media literacy. This is needed now more than ever, given the troubling problem of disinformation resulting from "fake news".

In a media context characterised by the exponential growth in the volume of content available and by the phenomenon of media convergence (Jenkins, 2008), the expansion and cultural transformation of the notion of audience is inevitable. Thus, the target audience, receiver, viewer or consumer of the past is now, above all, a holder of rights and obligations (Nieto-Tamargo, 2008) and a voracious consumer of content related predominantly to entertainment rather than just information.

An informed audience is one that makes use of complete, accessible and easily identifiable information on available audiovisual content. To be able to do this, information on programs must be sufficient, clear and precise. Rating and labelling programs can serve a guiding function provided that it includes a minimum combination of information: an age recommendation (suitable age) and a recommendation related to the type of content in moral terms. To be complete and useful, this moral recommendation should not only focus on potentially controversial elements (negative or harmful content) but should also indicate positive aspects. In this way, the moral recommendation can ensure a repertoire of information designed not only for protection, prevention or warning but also for the prescription of aspects that can contribute to the creation of a positive experience for viewers, while always respecting the individual's freedom to make the final decision. Rating and labelling systems thus ensure that viewer decisions can be based on quality information. At the same time, they encourage the social responsibility of media companies (Morales-Blanco-Steger; Fuente-Cobo, 2018) and content producers. The sum of all these effects is the advancement of effective media literacy.

An informed audience has implications in the following areas:

- Media companies are made aware of their corporate social responsibility. Media companies are essential actors for developing information on audiovisual content and making it available to audiences in a suitable, visible and accessible way.

- An informed audience is a more responsible audience. This significantly increases the likelihood of the audience exerting an influence on the audiovisual system through association membership, complaint mechanisms and involvement in forums with the active participation of the general public (associations of media users) arising from an organised and active best practice. Healthier media consumption is another logical effect of an informed audience.

- The rights of the general public are upheld through protection preventing the exposure of children to potentially harmful content, by providing the child's legal guardians with details and information to enable them to make better decisions while respecting their free choice. All of this affects the co-regulatory system currently in place in Spain, where the existence of voluntarily adopted self-regulation standards together with a mandatory legal framework can potentially create optimal conditions for ethical best practices in the media industry.

\subsection{Media literacy}

The biggest consequence of an effectively informed audience is media literacy, which has been studied extensively in Spain from the perspective of education (Aparici; García-Matilla, 1998; Pérez-Tornero; Varis, 2012; Ferrés, 2006; Aguaded, 2009; Ferrés; Piscitelli, 2012; Pérez-Tornero; Varis, 2012), and even applied to today's transmedia reality (Scolari, 2016; Azurmendi, 2018). In the Spanish-speaking world, the concept of media literacy has spread in parallel with the 
term educomunicación ("educommunication"), defined (Sena-Rivas et al., 2019; Vesga-Pérez, 2019).

"as a process that goes beyond mere training in reading and writing and involving critical analysis of messages, ethical and responsible content creation and interaction of the general public, where all participants become active agents in order to coexist in healthy environments based on democratic principles" (Marta-Lazo, 2018, p. 48).

In fact, the latest European audiovisual media services directive (European Union, 2018) includes a clarification (note 59) that defines media literacy more clearly than in previous legislation:
The biggest consequence of an effectively informed audience is media literacy

\begin{abstract}
"'Media literacy' refers to skills, knowledge and understanding that allow citizens to use media effectively and safely. In order to enable citizens to access information and to use, critically assess and create media content responsibly and safely, citizens need to possess advanced media literacy skills. Media literacy should not be limited to learning about tools and technologies but should aim to equip citizens with the critical thinking skills required to exercise judgment, analyse complex realities and recognise the difference between opinion and fact. It is therefore necessary that both media service providers and video-sharing platform providers, in cooperation with all relevant stakeholders, promote the development of media literacy in all sections of society, for citizens of all ages, and for all media, and that progress in that regard is followed closely."
\end{abstract}

Spain has two years to implement this new directive, which introduces changes and clarifies concepts: audiovisual media is considered in both programming and commercial terms; video sharing platforms and services are covered; the concept of editorial responsibility is clarified; and program labelling is recommended as an informational tool to make European production more visible and accessible.

In the final part of the directive, all actors involved are encouraged to promote the development of media literacy. In this respect, it is important to identify these actors, their responsibility, the scope of their potential contribution and their level of commitment. Following this mapping of the parties involved, the next step is to identify the skills that need to be developed for each actor. Various media literacy skills models have been proposed (see Table 1).

Table 1. Media literacy skills models

\begin{tabular}{|l|l|l|}
\hline \multicolumn{1}{|c|}{ Aparici \& Osuna-Acedo (2010) } & \multicolumn{1}{|c|}{$\begin{array}{c}\text { Ferrés \& Piscitelli (2012) } \\
\text { All have two dimensions: analysis } \\
\text { and expression }\end{array}$} & \multicolumn{1}{c|}{ Marta-Lazo \& Gabelas (2016) } \\
\hline Analyse and assign meaning to the information & Languages & Technocompetence (instrumental) \\
\hline $\begin{array}{l}\text { Understand the cultural and social implications of } \\
\text { technological convergence }\end{array}$ & $\begin{array}{l}\text { Technology } \\
\text { tion) }\end{array}$ & $\begin{array}{l}\text { Attitudinal (respect and empathy for other inte- } \\
\text { racting parties) }\end{array}$ \\
\hline $\begin{array}{l}\text { Understand and analyse the meaning of interac- } \\
\text { ting online }\end{array}$ & Interaction processes & $\begin{array}{l}\text { Axiological (Relationship, communication and in- } \\
\text { formation technologies, which are never neutral) }\end{array}$ \\
\hline $\begin{array}{l}\text { Identify the reliability and quality of online } \\
\text { information }\end{array}$ & $\begin{array}{l}\text { Production and } \\
\text { distribution processes }\end{array}$ & $\begin{array}{l}\text { Research (analysis and reflection for problem } \\
\text { solving) }\end{array}$ \\
\hline $\begin{array}{l}\text { Recognise who is represented and who is not in } \\
\text { the information }\end{array}$ & Ideology and values & Entrepreneurial (creative thinking) \\
\hline $\begin{array}{l}\text { Recognise the communicative and pedagogical } \\
\text { model of virtual environments }\end{array}$ & Aesthetics & Holistic (integrated learning) \\
\hline
\end{tabular}

These models represent a valuable approach from the perspective of education. Expanding the model to include all the actors involved requires some adaptation.

When we speak of competence we are referring to a set of knowledge, skills and attitudes considered necessary for a particular context. Specifically, media competence should contribute to the development of the personal autonomy of members of the general public, as well as their social and cultural commitment, according to Ferrés \& Piscitelli (2012, p. 69).

A media literacy policy should consider the following minimum skills: searching for and selecting information; understanding and interpreting content; personal critical assessment; channelling effective interaction (opinions, memberships, contributions, associated new creations); and identifying and participating in consultative, pre-legislative and/or self-regulatory forums. Each individual taking part in the audiovisual system and each stakeholder has different needs in relation to each skill. The set of skills that need to be prioritised for each audience should represent the first step towards a decisive, modern media literacy policy.

Informing the audience requires the rating and classification of content. Notable research on this question include studies by Tur-Viñes, Romero \& Lozano (2008), Fuente-Cobo, 2009 and Fuente-Cobo, Ortiz-Sobrino, Tur-Viñes, Martínez-Otero et al. (2015) and Tur-Viñes, Muñoz-Saldaña \& Mora-Figueroa-Monfort (2015).

Current initiatives are characterised by their special focus on the protection of children and of audiences with hearing disabilities. These are single-media initiatives with cinema or television in mind, with no consideration of media conver- 
gence. Below is an analysis of the most notable initiatives of different countries outside Spain.

\subsection{International TV rating systems}

The Australian model (ACMA, 2009) establishes mandatory requirements for television networks that broadcast children's programming, which are rated as either children's (C) or preschool children's (P) programs. The model defines specific time slots and takes holiday periods into account. It establishes a minimum number of hours to ensure that child audiences have sufficient programming. During children's programming there are restrictions on the amount of advertising ( 5 minutes every 30 minutes during " $\mathrm{C}$ " programs; no advertising at all during " $\mathrm{P}$ " programs) and content deemed potentially harmful to children is prohibited.

In the United States, the TV Parental guidelines (FCC, 1997) include an age recommendation and the following additional information, presented by superimposing the abbreviation in the top right corner of the screen:

- D (suggestive dialogue),

- L (coarse language),

- S (sexual situations),

- V (violence) and

- FV (fantasy violence).

Implementation is discretionary and has the advantage of being compatible with the "V-Chip" system, a device integrated into television sets since the year 2000 that allows parents to block programs they do not wish their children to watch.

In the United Kingdom, the media regulatory body, Ofcom, is responsible for overseeing compliance with the principles established in the Broadcasting code (Ofcom, 2019) designed to protect children from unsuitable or potentially harmful content. However, the United Kingdom does not have a rating system as such for television programming. As a result, rating processes fall under the purview of the British Board of Film Classification (BBFC), founded in 1912 for the film industry and responsible for classifying films, DVDs/videos and, in exceptional cases, some video games.

https://bbfc.co.uk

It is a private, independent non-profit organisation. It is also responsible for classifying video content for online distribution and commercial and internet content distributed on mobile networks, in accordance with a voluntary Code of best practices. It classifies content in seven categories based on an analysis of elements including: discrimination, drugs, sex, language and violence. With the aim of preserving its independence, $B B F C$ revenues come exclusively from what it charges for its classification services. The $B B F C$ is answerable for its activities to the British Parliament.

In The Netherlands, the protection of children from potentially harmful content on television, film, DVD, video games and services for mobiles has been addressed with great success through co-regulation. A crucial point for the success of this system is the participation, to differing degrees but collaboratively, of the Dutch government, the independent media regulation authority (Commissariaat voor de Media, CvdM), the media industry itself (either through the direct participation of media companies or indirectly through sector associations), and The Netherlands Institute for the Classification of Audio-visual Media (Nederlands Instituut voor de Classificatie van Audiovisual Media, Nicam), an intermediary body created, financed and operated by government agencies and the operators themselves.

https://www.cvdm.nl/en

http://www.kijkwijzer.nl/nicam

Nicam was established in 1999 as a tripartite initiative of the Ministry of Education, Culture and Science, the Ministry of Health, Welfare and Sport, and the Ministry of Justice. In February 2001, Nicam introduced the Kijkwijzer

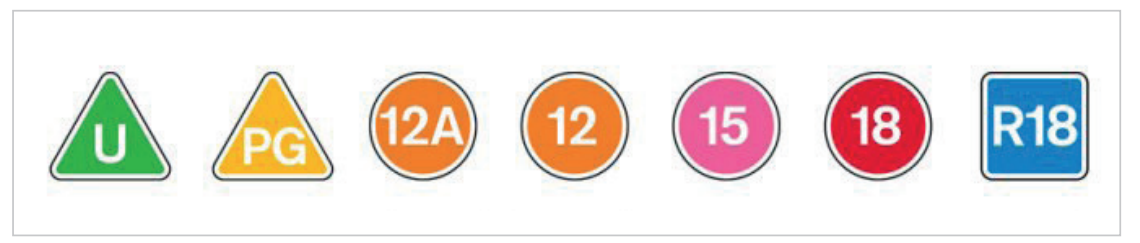
Image 2. Program classification in the United Kingdom (2019). Source: British Board of Film Classification (BBFC).

scheme, a rating system implemented by independent experts and currently managed by Mediawijzer.net, the Dutch centre for expertise in media literacy. The system applies to television programs, films, and video games, and since April 2005 it has been extended to certain audiovisual services accessible on mobile phones.

https://www.kijkwijzer.nl

https://www.mediawijzer.net/netwerk/partners/nicam-kijkwijzer 
Of all the cases examined here, the British and Dutch cases are worth highlighting. The system coordinated in the United Kingdom by the British Board of Film Classification (BBFC) is notable for its long history and continuity over time, its independent financing and operation, and its flexibility for integrating regulatory, self-regulatory and co-regulatory procedures. On the other hand, the Kijkwijzer/PEGI system created by Nicam in The Netherlands is implemented in 30 countries and could be considered the most widespread international initiative.

\section{Audiovisual ratings in Spain}

\subsection{Regulatory framework}

The first content regulation code, using diamond-shaped symbols, operated from 1963 to 1984 to regulate content on public television. It had only two levels: one diamond indicated content for viewers over 14 years of age, and two diamonds indicated content for viewers over 18.

It was in 2010 that the Spanish Film and Audiovisual Arts Institute (Instituto de la cinematografía y de las artes audiovisuales, ICAA) introduced a rating system based on age groups to classify films on different media and time restrictions on releases: movie theatres, DVDs, potential television broadcasts and online distribution. Penalties for breaches go up to a maximum of 4,000 euros.

http://www.culturaydeporte.gob.es/cultura/areas/cine/el-icaa.html

Also in 2010, Article 6.2 of the General audiovisual communication act (Ley general de comunicación audiovisual, LGCA) imposed the obligation on audiovisual media service providers to publish television programming at least 3 days in advance in electronic and online program guides. In compliance with this obligation, most audiovisual media service providers in the public sphere have made efforts to provide information on their programming content in the formats required; however, the information is not presented in a single, standardised form, as no applicable standards were established for the structure and content of such information.

In addition, Article 7.6 of the LGCA stipulates that all audiovisual products distributed on audiovisual media services must have an age-based rating, and that the competent audiovisual authority is responsible for oversight, regulation and penalties in relation to the program ratings published by providers of such services. All operators have exhibited a high level of compliance with these specifications.

The obligation of audiovisual media service providers to notify viewers of the recommended rating for each program by means of visual indicators and, in the case of content unsuitable for children, by an audible warning as well, is reflected in Article 7.2 of the LGCA. Although age-based ratings are common practice among all television operators, the quality of the

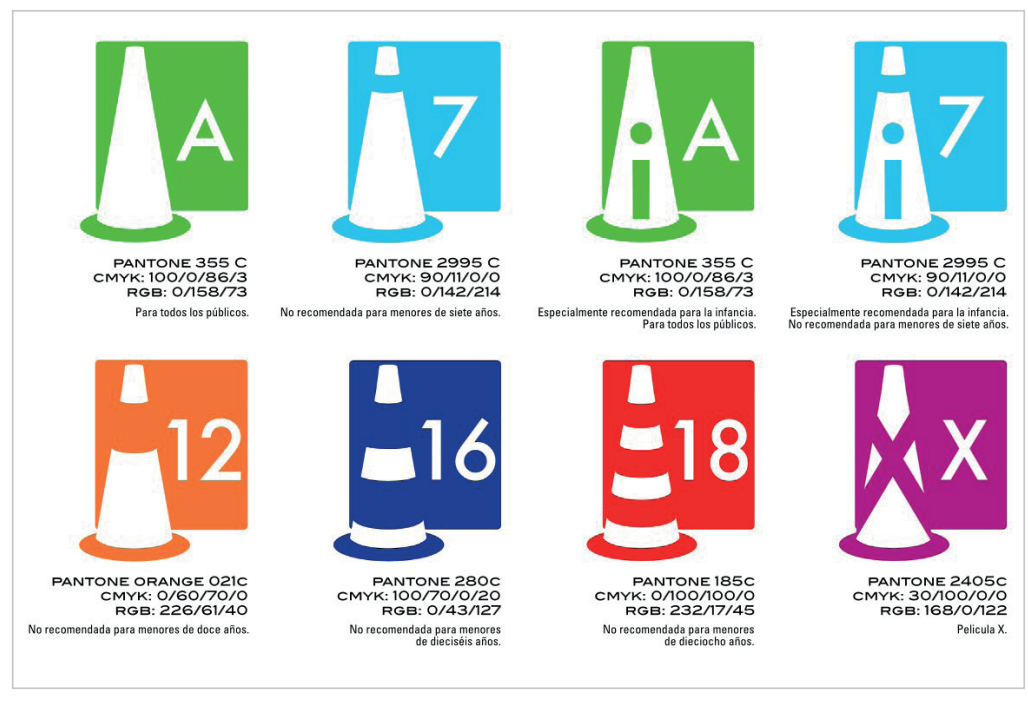

Image 4. Film ratings in Spain (2010).

Source: Instituto de la cinematografía y de las artes audiovisuales (ICAA).

information provided by means of age icons is insufficient and limited, and it would be helpful to complement it with other information systems aimed at facilitating more informed decisions about consumption based on personal sensitivity criteria (moral ratings) and not just age recommendations (age-based ratings). These two ratings together would ensure a more complete level of information.

The National Commission on Markets and Competition (Comisión Nacional de los Mercados y la Competencia, CNMC) is the administrative body responsible for maintaining the delicate balance between protection of the rights of freedom of expression, freedom of information, and free enterprise, and ensuring effective protection of children pursuant to Article 7 of the LGCA (Law 7/2010). It has powers of oversight, regulation and penalties in relation to the program ratings published by television service providers.

\subsection{Children's program ratings}

Children's content has received constant and increasing attention over the years, although the application of standards has been erratic. 
It was in 2004 that the Self-regulation code for television content and children was created as the result of a joint proposal by the public broadcaster Ente Público Radiotelevisión Española (now RTVE Corporation), the Antena 3 network owned by Televisión S.A. (now Atresmedia), Gestevisión Telecinco S.A., and Sogecable S.A. (both now owned by Mediaset). One year later, the Federation of Regional Radio and Television Organisations (Federación de Organismos de Radio y Televisión Autonómica, Forta), Sociedad Gestora de Televisión Net TV S.A., Unidad Editorial S.A. and Gestora de Inversiones Audiovisuales La Sexta S.A. (now Atresmedia) all subscribed to this Code.

The last update to this Code was in 2014 (following a previous update in 2011), at a time when CNMC's Telecommunications and Audiovisual Services division was acknowledging the need to incorporate additional mechanisms to strengthen the co-regulation described by the LGCA, rather than relying on the self-regulation system. When the target audience is children, there is a specific committee operated by the Joint Commission for Monitoring Compliance with the Self-regulation code for television content and children, which acts to ensure compliance with the Code in relation to age-based ratings of content. To channel user complaints and publish the annual activity reports, the Joint Commission created the TVInfancia initiative, made up of members of civil society organisations associated with the Code's purpose. TVInfancia now appears to be inactive (the last report uploaded to its website dates back to 2015).

Since its creation in 2007, the CNMC has prioritised the protection of children in audiovisual media. The development of criteria for rating audiovisual content was recognised as an urgent necessity. In 2014, the CNMC's Regulatory Oversight Tribunal created a working group made up of free-to-air television networks that subscribed to the Self-regulation code and the main consumer associations in the audiovisual sector, as well as experts in the field. The establishment of these thematic commissions to tackle different related projects is a regular practice of this public body (although independent from the government and subject to parliamentary and judicial oversight). This working group also held meetings with other service providers in the audiovisual sector. Specifically, to update the code (published in 2015) the CNMC set up a Children's Working Group made up of national operators and various associations (including iCmedia: the Federation of Media Consumer and User Associations) with the objective of creating a new rating system that would update the guiding principles of the Self-regulation code for television content and children. The CNMC provided the Working Group with a draft document produced under a research transfer agreement (Article 83 of the Organic law for universities), prepared by Carmen Fuente-Cobo and the author of this paper for iCmedia, a member of the working group. This report sought to facilitate the processes adopted by programmers/broadcasters in the allocation of age-based ratings to the programs being broadcast, to reduce the ambiguity of concepts and to enhance the degree of certainty for all actors on the audiovisual chain: operators/programmers, users and regulators.

An appendix to the 2015 Self-regulation code for television content and children included some guiding principles for rating television programs, recommended for voluntary application by linear and non-linear television service providers, irrespective of the broadcast medium used.

\subsection{The current rating system}

The current rating system applies only to fiction content. Informational, non-fiction and rebroadcast content is not subject to the rating obligation unless required by virtue of the nature of the content (boxing, wrestling, etc.).

The system contains a catalogue of 7 content types (see table 2) that are potentially harmful to children, 6 types that are positive for children and a series of modulating variables whose number varies depending on the type of potentially harmful content. Although the scientific literature does not reflect a consensus on the identification and significance of these risks, there is widespread agreement on the need to warn parents, educators and users in general about their presence in content that is accessible on different types of screens, in the interests of facilitating informed and responsible decision making. The rating age will be the highest one obtained out of the seven categories analysed (see image 5).

The most prevalent score for the variables described determines the age category. Films that were exhibited in Spain first in theatres and series that have their first release on home video will be classified by the ICAA. All other ratings will be determined by the teams of each television network.

The category of imitative behaviour as potentially harmful content and the identification of positive content and modulating variables are innovations that differentiate this system from all other existing models. These additional elements complement the information on age, provide details of content without the need to view it, anticipate decisions, provide a picture of children's household viewing diet, and facilitate the parent-child negotiation related to program viewing. This is useful information for preventing potentially negative effects while at the same time reinforcing the positive learning that children are receiving from other sources such as school and their immediate environment. As long as it is carefully administered for educational purposes, such information can never be excessive. 
Table 2. Guiding principles for rating television programs (Appendix to the 2015 Self-regulation code for television content and children)

\begin{tabular}{|l|l|l|l|}
\hline \multicolumn{1}{|c|}{$\begin{array}{c}\text { Potentially } \\
\text { harmful content }\end{array}$} & $\begin{array}{c}\text { Modulating variables } \\
\text { (contains adaptations to each type of } \\
\text { potentially harmful content) }\end{array}$ & Positive content \\
\hline Violence & Fleeting presence & Specially designed for children & Specially recommended for children \\
\hline Fear & Presence without significant consequences & Reinforces school curriculum \\
\hline Coarse language & Presence rebuked & Encourages values in children \\
\hline Sex & Unreal or fantasy presence & Encourages creativity \\
\hline Drugs & Explicit and realistic presence & Encourages integration of minorities \\
\hline Discrimination & Detailed presence & Encourages healthy habits \\
\hline Imitative behaviour & Realistic or frequent presence & & 12 \\
\hline & Explicit and positive presence & & 16 \\
\hline & Glorification or revelling & & \\
\hline
\end{tabular}

\begin{tabular}{|c|c|c|c|c|c|c|c|c|c|}
\hline 3.1. VIOLENCIA & $\begin{array}{l}\text { Presencia } \\
\text { accesoria, } \\
\text { mínima o } \\
\text { fugaz }\end{array}$ & $\begin{array}{l}\text { Presencia sin } \\
\text { consecuencias } \\
\text { relevantes }\end{array}$ & $\begin{array}{l}\text { Presentación } \\
\text { negativa o } \\
\text { claramente } \\
\text { reprochada }\end{array}$ & $\begin{array}{c}\text { Presencia o } \\
\text { presentación leve, } \\
\text { irreal o fantástica y } \\
\text { no detalladada }\end{array}$ & $\begin{array}{l}\text { Presencia } \\
\text { explicita y } \\
\text { realista }\end{array}$ & $\begin{array}{l}\text { Presentación real o } \\
\text { realista y detallada }\end{array}$ & $\begin{array}{l}\text { Presencia } \\
\text { explicita, real o } \\
\text { realista, y } \\
\text { detallada o } \\
\text { frecuente } \\
\end{array}$ & $\begin{array}{c}\text { Presencia explíitita y detallada o } \\
\text { positiva, con utilización de recursos } \\
\text { potenciadores del impacto }\end{array}$ & $\begin{array}{l}\text { Exaltación de la violencia o } \\
\text { recreación en el sufrimiento } \\
\text { de la victima }\end{array}$ \\
\hline $\begin{array}{l}\text { 3.1.1. Violencia fisica: usa intencionado de la } \\
\text { fuerza fisica generando daños en la victima } \\
\text { (personas, animales, naturaleza): heridas, } \\
\text { lesiones, mutilaciones, muerte o destrucción, } \\
\text { tortura, secuestro }\end{array}$ & TP & TP & +7 & +7 & +12 & +12 & +16 & +18 & +18 \\
\hline 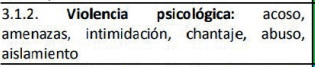 & TP & TP & +7 & +7 & +12 & +12 & +16 & +18 & +18 \\
\hline $\begin{array}{l}\text { 3.1.3. Violación de los derechos humanos y } \\
\text { actos contrarios a la libertad o a la dignidad } \\
\text { humana: Tráfico de personas, esclavitud, } \\
\text { trata de blancas, proxenetismo }\end{array}$ & +7 & +7 & +7 & +7 & +12 & +12 & +16 & +18 & +18 \\
\hline $\begin{array}{l}\text { 3.1.4. Violencia de género: violencia física o } \\
\text { psicológica contra una persona por razón de } \\
\text { su sexo o tendencia sexual }\end{array}$ & +7 & +7 & +7 & +7 & +12 & +12 & +16 & +18 & +18 \\
\hline $\begin{array}{l}\text { 3.1.5. Violencia doméstica: violencia física o } \\
\text { psicológica entre miembros de una familia. } \\
\text { Maltrato infantil o a personas dependientes o } \\
\text { con discapacidad }\end{array}$ & +7 & +7 & +7 & +7 & +12 & +12 & +16 & +18 & +18 \\
\hline 3.1.6. Violación, abusos sexuales & +7 & +7 & +12 & +12 & +16 & +16 & +18 & +18 & +18 \\
\hline
\end{tabular}

Image 5. Rating model for violent content (2015).

Source: CNMC, 2015.

The combination of age recommendations and warnings about content that is potentially harmful (or positive) for the developmental stage of each child effectively addresses the diversity of needs of children arising from the inevitable natural differences in their personal development, independently of chronological age.

At the same time, the inclusion of the positive aspects of each program prevents the perception of the system as a "censorship" regime, positioning it more clearly as a balanced, integral "informational" system designed to facilitate family decisions related to audiovisual consumption. This aspect alone positions the Spanish rating system among the new innovations in media regulation that reject an apocalyptic view, promoting an objective consideration of content and contributing to the creation of an informed audience. This perspective facilitates a more realistic understanding of the genuine complexity of audiovisual content and its effects on under-age viewers, addressing both preventive and formative dimensions. Viewers are the final beneficiaries as they have more information to decide what to watch at any given moment, but at the same time, television operators are able to implement positive recommendation policies that complement the preventive recommendation policies that are more typical of the international rating systems analysed above.

In 2015, the CNMC resolved to confirm the replacement of the rating criteria contained in the Appendix to the Self-regulation code for television content and children enacted in 2007. The age-based recommendation notice is mandatory. However, the indication of positive and negative content is included solely as a recommendation. The activity of audience consultation, the interaction and complaint channels available for audiences to share their opinions, and the pressure from television viewer and user associations (which are very active in Spain) will be decisive in making these changes meaningful and bringing about the improvements needed to the system in the future. Operators, regulators, producers and audiences will be the first to benefit thanks to a rating system that can serve as a truly useful tool for the formation of more competent, literate under-age viewers.

It is to be hoped that in future updates to the system the indication of negative and positive content will be adopted by more television networks and that it will be extended to all other media where content for children can be viewed, even if its actual application at present is limited to television. To turn the system into a truly powerful tool for promoting literacy, future updates should consider the incorporation of informational pictograms. Electronic program guides (EPGs) and existing technologies faci-

As long as it is carefully administered for educational purposes, such information can never be excessive 
litate the implementation of an information system for labelling programs based on pictograms. The key to the success of such a system lies in choosing easily understandable and technically viable designs.

Pictogram-based systems (Tur-Viñes, 2016) have demonstrated their usefulness in conveying information to the general public in fields like signage and product labelling, among others. Notable advantages of such systems include,

- faster processing of the information they provide;

- ability to convey information regardless of the consumer's language or educational level;

- usefulness for people with visual impairments; and

- capacity for capturing the attention of the consumer.

Disadvantages include,

- the fact that consumers may be unfamiliar with their meaning;

- their design may be incomprehensible, or

- extended periods of time and information campaigns needed to make consumers aware of them.

In 2016, an exploratory study (Tur-Viñes, 2016) financed by iCmedia under a transfer agreement tested various pictogram designs to support the guiding principles for rating television programs. http://www.icmedianet.org/es/quienes-somos

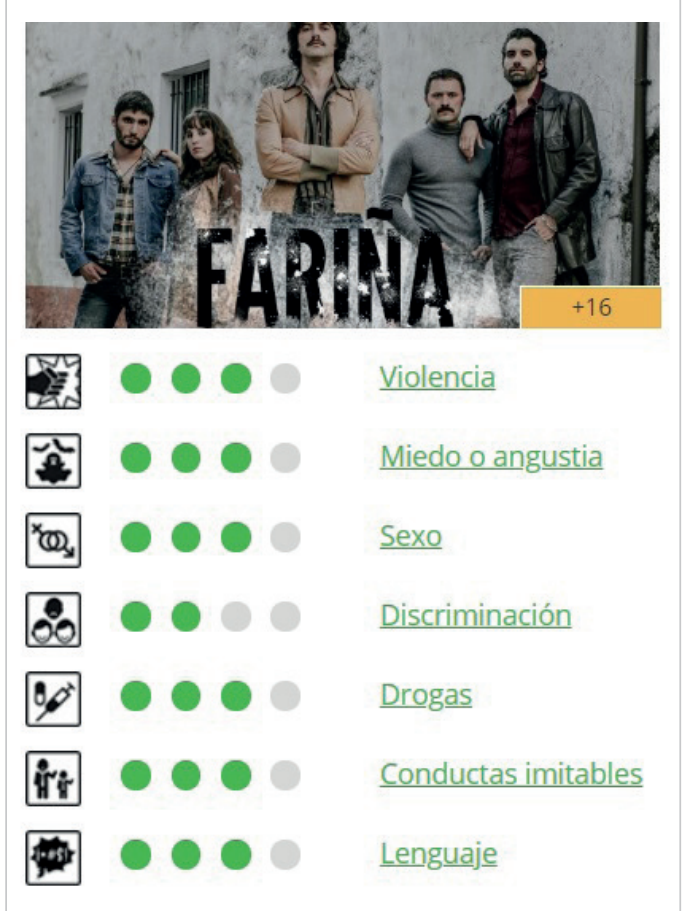

Image 6. Example of pictogram ratings.

Source: iCmedia.

With the aim of measuring levels of comprehension, recollection and recognition of the pictograms, an eye-tracking technique was used on a convenience sample of 50 participants. The result facilitated the selection of designs currently being used by iCmedia in a pilot initiative aimed at creating an audiovisual trust seal. This is an initiative of great significance given its direct impact on audience literacy. The kind of information that pictograms provide can be seen in the rating for the series Fariña determined by iCmedia (see Image 6).

\section{Conclusions}

Audiovisual content rating systems can be both evaluative and descriptive,

- evaluative ratings offer an age-based recommendation for viewers;

- descriptive ratings provide added value of a moral and preventive nature, warning parents, guardians and children themselves about potentially harmful content that can be identified for the purpose of formulating a personal opinion and deciding whether or not to choose and view that content.

Evaluative ratings are more common in the realm of regulation and self-regulation and have a simple application, while descriptive ratings provide more detailed information that helps users to make informed decisions. The systems that are most useful for creating an informed audience are mixed systems that combine evaluation and description.

Spain has a mixed model, resulting from an initiative aimed at protecting children as an audience, as well as people with hearing impairments. This model is self-regulatory, implemented by television operators. In the sphere of television, the most extensive project in program ratings is based on the Self-regulation code for television content and children, which provides for the creation of two bodies to oversee compliance:

- a Self-Regulation Committee with the responsibility for resolving doubts and managing complaints related to its application; and

- a Joint Commission for Monitoring Compliance to follow up on decisions that are not being implemented.

The Self-Regulation Committee contains representatives from the participating television networks, which is unusual because any self-regulation system should have an external, independent and objective body responsible for resolving disputes. Television networks cannot act as both judges and defendants. Moreover, complaints related to advertising are processed by the advertising regulatory board Autocontrol (a non-profit organisation), also program complaints, incomprehensibly.

Such a conflict of interest is not positive for the optimal operation of the system and could explain why in 2018 a total of only 87 complaints were processed by TVInfancia, of which 39 were dismissed. Of the complaints processed, 43 were related to television programming (26 on $\mathrm{Me}$ diaset España; 6 on Atresmedia, 2 on Forta, 1 on Ten, and 1 on Net.TV) and 5 were related to advertising content. The Self-Regulation Committee determined that the programming should be cancelled in 3 cases, adding

The inclusion of the positive aspects of each program prevents the perception of the system as a "censorship" regime, positioning it more clearly as a balanced, integral "informational" system 
a recommendation to the operator not to repeat it in the future. The Committee's activity has decreased in comparison with previous years, and it has not proven very effective, with response times that are inadequate for the dynamics of television programming. In view of the data, the mechanisms for overseeing the application of the Code do not seem to be the best, as they compromise the effective implementation of the system established in the appendix to the Code related to program ratings. The system urgently needs to be redesigned in order to continue to fulfil the function for which it was created: the effective protection of children as a television audience.

The current television rating system has some innovative features compared to models in other countries, such as the inclusion of imitative behaviour as potentially harmful content and the identification of positive content and modulating variables for ratings. However, it is a system that requires specialised training for the people responsible for implementing it at the television networks; this aspect has not been taken into account and is now emerging as a matter in need of attention.

An update to the rating system is also needed because it is based on an initiative designed exclusively for television. In the current context of media convergence, single-media rating systems are seriously out of place. Its adaptation for social media and content generated and broadcast by users themselves would make for information more in keeping with the media reality in which we live today. The responsibility for information on content falls in practice upon television networks, but the video-sharing platforms that are now so dominant in the sector also need to provide this type of labelling on the videos they offer in order to contribute to safer consumption. On the other hand, individual creators also have informational and editorial responsibility for the content they share with their communities of followers.

At the same time, on the administrative level, an independent body is urgently needed for effective handling of the complaints of viewers who are becoming increasingly aware of the decisive role they play in the system. A self-regulatory framework characterised by best practice agreements and codes designed as voluntary guidelines promoted by the actors involved is the ideal approach. Concerted efforts to raise awareness about the existence of the Code and the rating system would also contribute to more effective implementation. It is hoped that this paper may contribute to this.

Activities to promote literacy in relation to content ratings to help guide parents or guardians, teachers, youth and children are essential in this era of media convergence. Such activities effectively contribute to the successful implementation of content rating policies. The mandatory implementation of the Audiovisual media services directive represents an important challenge for the decisive consolidation of policies that will promote a media-literate audience.

\section{References}

Abalasei, Beatrice (2012). "Types of audience attending sports events in Romania". Procedia-social and behavioral sciences, v. 46, pp. 3482-3486.

https://doi.org/10.1016/j.sbspro.2012.06.089

ACMA (2009). Childrens television standards. Australian Communications and Media Authority. https://www.acma.gov.au/sites/default/files/2019-06/Previous-guide-to-the-Childrens-Television-Standards-2009.pdf

Aguaded, Ignacio (2009). “El Parlamento Europeo apuesta por la alfabetización mediática”. Comunicar, v. 16, n. 32, pp. 7-8. https://doi.org/10.3916/c32-2009-00-001

Aparici, Roberto; García-Matilla, Agustín (1998). Lectura de imágenes. Madrid: Ediciones De la Torre (1a ed. 1987). ISBN: 8486587603

Aparici, Roberto; Osuna-Acedo, Sara (2010). “Educomunicación y cultura digital”. En: Aparici, Roberto (coord.). Educomunicación: más allá del 2.0. Barcelona: Gedisa. ISBN: 9788497846059

Aznar-Gómez, Hugo (2002). "Televisión, telebasura y audiencia: condiciones para la elección libre”. Revista latina de comunicación social, v. 5, n. 48.

https://repositorioinstitucional.ceu.es/handle/10637/6938

Azurmendi, Ana (2018): "Reconectar con la audiencia joven. Narrativa transmedia para la transformación de la televisión de servicio público en España, Francia, Alemania y Reino Unido". Revista latina de comunicación social, n. 73, pp. 927-944. https://doi.org/10.4185/RLCS-2018-1289

BBFC (2019). British Board Film Classification.

https://bbfc.co.uk

CNMC (2015). Sistema de calificación por edades de productos audiovisuales. Código de autorregulación sobre contenidos televisivos e infancia. Criterior/DTSA/001/15. Comisión Nacional de los Mercados y la Competencia.

http://bit.ly/2LGVGVK 
Commissariaat voor de Media.

https://www.cvdm.nl/en

Cover, Rob (2006). "Audience inter/active: Interactive media, narrative control and reconceiving audience history". New media \& society, v. 8, n. 1, pp. 139-158.

https://doi.org/10.1177/1461444806059922

Dahlberg, Lincoln (2007). "The internet, deliberative democracy, and power: Radicalizing the public sphere". International journal of media \& cultural politics, v. 3, n. 1, pp. 47-64.

https://doi.org/10.1386/macp.3.1.47_1

Dahlgren, Peter (1995). Television and the public sphere: Citizenship, democracy and the media. Sage. ISBN: 9780 803989238

España (2010). “Ley 7/2010, de 31 de marzo, General de la comunicación audiovisual”. BOE, n. 79, 1 abril. https://www.boe.es/buscar/pdf/2010/BOE-A-2010-5292-consolidado.pdf

European Union (2018). "Directiva (UE) 2018/1808 del Parlamento Europeo y del Consejo de 14 de noviembre de 2018 por la que se modifica la Directiva 2010/13/UE (Directiva de servicios de comunicación audiovisual)". Diario oficial de la Unión Europea, L303/69, 28 de noviembre.

https://www.boe.es/doue/2018/303/L00069-00092.pdf

FCC (1997). TV parental guidelines. Federal Communications Commission

http://www.tvguidelines.org

Federación de Asociaciones de Consumidores y Usuarios de los Medios (iCmedia). http://www.icmedianet.org/es/quienes-somos

Ferrés, Joan (2006). "La competencia en comunicación audiovisual: propuesta articulada de dimensiones e indicadores". Quaderns del CAC, n. 25, pp. 9-17.

https://www.cac.cat/es/documentacio/la-educacion-comunicacion-audiovisual

Ferrés, Joan; Piscitelli, Alejandro (2012). “La competencia mediática: propuesta articulada de dimensiones e indicadores". Comunicar, v. 19, n. 38, pp. 75-82.

https://doi.org/10.3916/C38-2012-02-08

Fuente-Cobo, Carmen (coord.) (2009). Infancia y televisión. Políticas de protección de los menores ante los contenidos audiovisuales. Madrid: Fragua. ISBN: 9788470742965

Fuente-Cobo, Carmen; Ortiz-Sobrino, Miguel-Ángel; Tur-Viñes, Victoria; Martínez-Otero, Juan; Muñoz-Saldaña, Mercedes; Mora-Figueroa-Monfort, Borja (2015). Criterios y procedimientos de calificación de contenidos audiovisuales. Madrid: Instituto de Radio y Televisión Española (Irtve). ISBN: 9788488788948

Hagen, Ingunn (1997). "Communicating to an ideal audience: News and the notion of the 'informed citizen'”. Political communication, v. 14, n. 4, pp. 405-419.

https://doi.org/10.1080/105846097199209

Hartley, John (1999). Uses of television. London, UK: Routledge. ISBN: 9780415085083

Instituto de Cinematografía y de las Artes Audiovisuales (ICAA).

http://www.culturaydeporte.gob.es/cultura/areas/cine/el-icaa.html

Jenkins, Henry (2008). Convergence culture. La cultura de la convergencia de los medios de comunicación. Barcelona: Paidós. ISBN: 9788449321535

Kijkwijzer (2001). The Dutch rating system for audiovisual productions.

https://www.kijkwijzer.nl

Marta-Lazo, Carmen (2018). “El marco teórico de la alfabetización mediática: orígenes, fundamentos y evolución conceptual”. En: Fuente-Cobo, Carmen; García-Galera, María-del-Carmen; Camilli-Trujillo, Celia-Rosa (eds.). La educación mediática en España: artículos seleccionados. Universitas Editorial, pp. 47-54. ISBN: 9788479914899

Marta-Lazo, Carmen; Gabelas, José-Antonio (2016). Comunicación digital. Un modelo basado en el factor r-elacional. Barcelona: Editorial UOC. ISBN: 9788491164715

Marton, Ference; Säljö, Roger (1984). “Cognitive approach in learning”. In: Marton, Ference; Hounsell, Dai; Entwistle, Noel (eds.). The experience of learning. Edinburgh: Scottish Academic. Press. ISBN: 0707303559

Mediawijzer.net (2008).

https://www.mediawijzer.net/netwerk/partners/nicam-kijkwijzer 
Morales-Blanco-Steger, Begoña; Fuente-Cobo, Carmen (2018). "Confianza de las audiencias en las marcas televisivas: propuesta de indicadores de responsabilidad social y reputación corporativas". El profesional de la información, v. 27, n. 3, pp. 537-547.

https://doi.org/10.3145/epi.2018.may.07

Nicam (2001). Netherlands Institute for the Classification of Audiovisual Media. http://www.kijkwijzer.nl/nicam

Nieto-Tamargo, Alfonso (2008). “Ciudadano y mercado de la comunicación”. Comunicación y sociedad, v. 21, n. 2, pp. 7-33. https://dadun.unav.edu/handle/10171/8493

Ofcom (2019). The Ofcom broadcasting code (with the cross-promotion code and the on demand programme service rules). https://www.ofcom.org.uk/_data/assets/pdf_file/0016/132073/Broadcast-Code-Full.pdf

Pérez-Tornero, José-Manuel; Varis, Tapio (2012). Alfabetización mediática y nuevo humanismo. Barcelona: Editorial UOC. ISBN: 9788497885126

Quintas-Froufe, Natalia; González-Neira, Ana (coord.) (2015). La participación de la audiencia en la televisión: de la audiencia activa a la social. Madrid: AIMC. ISBN: 9788460842422 https://www.aimc.es/a1mc-cOnt3nt/uploads/2017/05/2016_01participacion_audiencia_tv.pdf

Quintas-Froufe, Natalia; González-Neira, Ana (2016). “Consumo televisivo y su medición en España: camino hacia las audiencias híbridas". El profesional de la información, v. 25, n. 3, pp. 376-383.

https://doi.org/10.3145/epi.2016.may.07

Saavedra-Llamas, Marta; Rodríguez-Fernández, Leticia; Barón-Dulce, Gemma (2015). “Audiencia social en España: estrategias de éxito en la televisión nacional". Icono14, v. 13, n. 2, pp. 214-237.

https://doi.org/10.7195/ri14.v13i2.822

Scolari, Carlos A. (2016). "Alfabetismo transmedia: estrategias de aprendizaje informal y competencias mediáticas en la nueva ecología de la comunicación". Telos, n. 103, pp. 13-23.

https://telos.fundaciontelefonica.com/archivo/numero103/estrategias-de-aprendizaje-informal-y-competenciasmediaticas-en-la-nueva-ecologia-de-la-comunicacion

Sena-Rivas, Wiselis-Rosanna; Casillas-Martín, Sonia; Barrientos-Báez, Almudena; Cabezas-González, Marcos (2019). "La educomunicación en el contexto de alfabetización de personas jóvenes y adultas en América Latina: estado de la cuestión a partir de una revisión bibliográfica sistemática". Revista latina de comunicación social, n. 74, pp. $133-171$. http://www.revistalatinacs.org/074paper/1325/08es.html https://doi.org/10.4185/RLCS-2019-1325

Tur-Viñes, Victoria (2015). “Engagement, audiencia y ficción”. En: Rodríguez-Ferrándiz, Raúl; Tur-Viñes, Victoria (coords.). Narraciones sin fronteras. Transmedia storytelling en la ficción, la información, el documental y el activismo social y político. Cuadernos Artesanos de Comunicación, n. 81. Tenerife: Sociedad Latina de Comunicación Social, pp. 41-60. ISBN: 9788415698968.

https://doi.org/10.4185/cac81

Tur-Viñes, Victoria (2016). “Propuesta de pictogramas para la clasificación audiovisual en España”. En: García-García, Francisco; Taborda-Hernández, Ernesto (coords.). I Congreso de cine e imagen científicos, pp. 669-685. ISBN: 978 84 93807092 http://bit.ly/2LBy6df

Tur-Viñes, Victoria; Lozano-Oyola, Macarena; Romero-Landa, Luis-Benjamín (2008). “Contenidos programáticos audiovisuales: experiencias internacionales en regulación". Sphera pública. Revista de ciencias sociales y de la comunicación, n. 8, pp. 41-63.

http://sphera.ucam.edu/index.php/sphera-01/article/view/67

Tur-Viñes, Victoria; Muñoz-Saldaña, Mercedes; Mora-Figueroa-Monfort, Borja (2015). “Análisis internacional de modelos de clasificación de contenidos". En: Fuente-Cobo, Carmen; Ortiz-Sobrino, Miguel-Ángel; Tur-Viñes, Victoria; Martínez-Otero, Juan; Muñoz-Saldaña, Mercedes; Mora-Figueroa-Monfort, Borja. Criterios y procedimientos de calificación de contenidos audiovisuales. Madrid: Instituto de Radio y Televisión Española (Irtve). ISBN: 9788488788948

TVInfancia.

https://tvinfancia.es/tvinfancia

Vesga-Pérez, Óscar (2019). "Educomunicación, a través de la creación audiovisual: tres experiencias en Colombia". Revista latina de comunicación social, n. 74, pp. 1452-1469.

http://www.revistalatinacs.org/074paper/1393/76es.html

https://doi.org/10.4185/RLCS-2019-139 